\title{
The ecology of gadid fishes in the circumpolar Arctic with a special emphasis on the polar cod (Boreogadus saida)
}

\author{
Franz J. Mueter $^{1} \cdot$ Jasmine Nahrgang $^{2,3} \cdot$ R. John Nelson ${ }^{4} \cdot$ Jørgen Berge $^{2,3}$
}

Published online: 19 May 2016

(C) Springer-Verlag Berlin Heidelberg 2016

In high-Arctic marine ecosystems, the gadids Boreogadus saida (Lepechin, 1774) and Arctogadus glacialis, hereafter referred to as polar cod and Arctic cod, as respective European common names, are foundation species that make up important links between lower and higher trophic levels of the food web (Bradstreet et al. 1986; Christiansen et al. 2012; Hop and Gjøsæter 2013). Other Arctic gadids considered here are the saffron cod [Eleginus gracilis (Tilesius, 1810)], which is endemic to the Pacific Arctic but extends into boreal waters as far south as Japan (Mecklenburg et al. 2002), and its Atlantic sister species, the navaga [Eleginus navaga (Walbaum, 1792)], which is limited to European Arctic and subarctic waters of the Barents, White and Kara seas (Cohen et al. 1990). There is a strong imbalance in the scientific literature regarding these species-a search for the words "Boreogadus" in Google Scholar (April 2016) resulted in 4010 hits, compared to only 522 hits for "Arctogadus," reflecting a greater emphasis on the more abundant polar cod. The genus "Eleginus" resulted in 1480 hits (E. gracilis: 1070;

This article belongs to the special issue on the "Ecology of Arctic Gadids," coordinated by Franz Mueter, Jasmine Nahrgang, John Nelson and Jørgen Berge.

Franz J. Mueter

fmueter@alaska.edu

1 School of Fisheries and Ocean Sciences, University of Alaska Fairbanks, Juneau, AK 99801, USA

2 Department of Arctic and Marine Biology, UiT The Arctic University of Norway, 9037 Tromsö, Norway

3 The University Centre in Svalbard, 9171 Longyearbyen, Norway

4 University of Victoria, Victoria, BC V8W 3N5, Canada
E. navaga: 408), reflecting the importance of saffron cod as a subsistence resource in parts of the North Pacific.

While research on B. saida has a long history, particularly in Russia (Andriyashev 1954; Rass 1968; Ponomarenko 2000; Boitsov et al. 2013), interest in Arctic marine ecosystems has grown in recent years as summer sea ice cover has diminished and water temperatures have increased (Wang and Overland 2009). Arctic gadids, in particular polar cod, have been a focal point for studies of climate impacts (Fortier et al. 2006; Benoit et al. 2008; Bouchard and Fortier 2008; Renaud et al. 2012) and pollution impacts (Christiansen and George 1995; Nahrgang et al. 2010; Dussauze et al. 2014; Geraudie et al. 2014; Andersen et al. 2015). Yet, our current understanding of these important Arctic species is surprisingly fragmented and inconclusive, leaving major gaps in knowledge that prevent a holistic understanding of the interaction between these species and their environment.

This special issue contains a collection of manuscripts from an international workshop on the ecology of circumpolar Arctic gadids. The workshop was convened during the Ecosystem Studies of the Subarctic and Arctic Seas (ESSAS) Annual Science Meeting, 8-9 April 2014, in Copenhagen, Denmark. Four of the papers in this collection take a comparative approach across species: Bouchard et al. (2016) compare the early life history of polar cod and Arctic cod, Laurel et al. (2016) contrast the growth rates of four gadids in the North Pacific under different temperatures, Kunz et al. (2016) compare growth of polar cod and Atlantic cod (Gadus morhua) under different temperatures and $\mathrm{CO}_{2}$ levels, and McNicholl et al. (2015) compare diets of two potential competitors, polar cod and capelin (Mallotus villosus). A single paper focuses on saffron cod, specifically their trophic dynamics as inferred from several trophic biomarkers (Copeman et al. 2016). The remaining 
12 papers describe studies on various aspects of polar cod only. These include studies of ecotoxicology (Bakke et al. 2016), population genetics (Madsen et al. 2016), distribution and habitat use (Astthorsson 2016; Crawford 2016; David et al. 2016; Geoffroy et al. 2016; Kessel et al. 2016; Kono et al. 2016), diets of juveniles and adults (Gray et al. 2016; Majewski et al. 2016; Nakano et al. 2016) and reproductive biology (Nahrgang et al. 2016). Combined, the current special issue is, at least in the western scientific literature, so far the largest single step forward in our understanding of the ecology, life history and distribution of Arctic gadids in a changing Arctic. Below, we present a brief synopsis of papers in the special issue, as well as some context leading up to the work described.

\section{Distribution in the Arctic and habitat preferences}

Polar cod and Arctic cod have a pan-Arctic distribution and are regularly observed in association with Arctic sea ice. Both have antifreeze glycoproteins to survive long periods at sub-zero temperatures (Pörtner and Playle 1998), but neither can be regarded as a primarily ice-associated species. Rather, they should be considered a demersal or semipelagic species with a preference for pelagic prey items (Süfke et al. 1998; McNicholl et al. 2015; Gray et al. 2016; Majewski et al. 2016; Nakano et al. 2016). Their distributions overlap, but polar cod extend to lower latitudes than Arctic cod (Mecklenburg and Steinke 2015; Madsen et al. 2016; Bouchard et al. 2016). The latter has a more restricted distribution and appears to be absent from the Central Arctic Basin (Mecklenburg and Steinke 2015). In contrast, polar cod (primarily 1-year-old fish) are ubiquitous under the sea ice throughout the central Arctic Ocean in the Canadian Basin (Melnikov and Chernova 2013) and the Eurasian Basin, where fish in good energetic condition have been observed in relatively high densities up to an estimated 15,920 individuals $\mathrm{km}^{-2}$ (David et al. 2016). These fish likely originate on the Arctic shelves, and it is unclear how their distribution will be affected by further shortening of the ice-covered season and reduced sea ice extent (David et al. 2016). The vertical distribution of polar cod changes from a strong surface orientation of egg and larval stages (Bouchard et al. 2016; Geoffroy et al. 2016) to deeper waters, including demersal habitats, at the end of their first year (Geoffroy et al. 2016).

The distribution of Arctogadus spp. is poorly described, partly because their taxonomy remains uncertain, with some authors distinguishing at least two species [A. borisovi (Dryagin, 1932) and A. glacialis (Peters, 1872)] in the Atlantic Arctic based on classical taxonomic studies (Natalia Chernova, Russian Academy of Sciences, pers. comm.). Others consider A. glacialis to be a single circumpolar species based on morphology and genetics (Jordan et al. 2003; Aschan et al. 2009; Mecklenburg et al. 2014; Mecklenburg and Steinke 2015). In both the Atlantic and the Pacific Arctic, A. glacialis overlaps with B. saida, but is generally much less abundant (Madsen et al. 2016; Bouchard et al. 2016). For example, only 8-9 \% of larval cod sampled in the Amundsen Gulf were classified as $A$. glacialis (Bouchard et al. 2016). Local exceptions, however, are reported from the Northeast Water Polynya off NE Greenland in 1990 (von Dorrien et al. 1991).

Saffron cod are distributed along the coastlines of the North Pacific Ocean, extending through the Bering Strait northward into the Chukchi, East Siberian and Beaufort seas and as far east as Nunavut (Cohen et al. 1990). In contrast to polar cod and Arctic cod, they primarily inhabit brackish to marine waters at relatively shallow depths up to $75 \mathrm{~m}$ (Wolotira 1985). They are often found in areas of tidal influence at the mouths of coastal rivers (Wolotira 1985), where they can reach locally high abundances and serve as an important food for Arctic seabirds and marine mammals (Bluhm and Gradinger 2008). Reflecting their more southern and nearshore distribution, saffron cod are able to grow and store excess lipids at temperatures as high as $20{ }^{\circ} \mathrm{C}$ (Copeman et al. 2016; Laurel et al. 2016), suggesting a competitive advantage over polar cod in a warming climate.

The polar cod is the most abundant Arctic gadid and occupies a wide variety of habitats including nearshore waters, semi-enclosed bays, Arctic and subarctic shelves, continental slope regions and the Central Arctic Basin (Drolet et al. 1991; Michaud et al. 1996; Hop et al. 1997; Norcross et al. 2010; Logerwell et al. 2015; Mecklenburg and Steinke 2015; David et al. 2016; Kessel et al. 2016). Relatively large abundances occur in the western Beaufort Sea (Benoit et al. 2008) and in the eastern and northern Barents Sea, where they have supported a modest-sized fishery of up to 50,000 t in recent decades (Hop and Gjøsæter 2013; McBride et al. 2014). More recently, large aggregations of young-of-year polar cod were observed in the northeast Chukchi Sea (De Robertis et al. 2016), but their origin remains unknown. Biomass estimates in the Barents Sea region peaked at 2 million $t$ in 2006, but have declined to less than $300,000 \mathrm{t}$ in 2014 in spite of relatively conservative exploitation rates between 0 and $4 \%$ that are believed to have little impact on stock dynamics (McBride et al. 2014; Havforskningsrapporten 2015; Pavel Krivosheya, PINRO, Murmansk, pers. comm.). Reductions in abundance may be related to increasing abundances of potential competitors such as capelin (Hop and Gjøsæter 2013; McNicholl et al. 2015) or predators such as larger gadids (Nahrgang et al. 2014). However, the distribution of polar cod has recently shifted toward the northeast, into the Russian zone of the Barents Sea, where the survey 
coverage has been poorer with no catches in 2014 (Havforskningsrapporten 2015). Thus, some of the apparent decline can likely be explained by a shift in stock distribution. At the very edges of their distribution around Iceland, polar cod have been encountered less frequently in fishery surveys during recent years, which may be related to increasing bottom water temperatures; this may eventually lead to their disappearance from Icelandic waters (Astthorsson 2016). Similarly, the abundances of several Arctic species, including polar cod, decrease in years with reduced sea ice cover in the Bering Sea (Mueter and Litzow 2008) and where the polar frontal zone has retreated in the Barents Sea during recent warm years (Fossheim et al. 2015). Monitoring polar cod using existing fishery surveys therefore provides a good indicator of changes in the subArctic-Arctic ecotone.

\section{Population genetics}

Little is known regarding stock structure in polar cod or the other Arctic gadids. Genetic variation across the broad geographic range occupied by polar cod is relatively low (Nelson and Bouchard 2013; Mecklenburg and Steinke 2015), with some genetic variation at regional scales. Specifically, Madsen et al. (2016) showed significant population differentiation between polar cod inside fjords of northeast Greenland and Svalbard relative to populations on the shelf. The differentiation, albeit weak, was most pronounced between Svalbard and northeast Greenland. The authors speculate that the fjord populations may have become genetically isolated from populations on the shelf during recolonization after the last glacial maximum.

\section{Life cycle strategies}

Knowledge of the life history strategies of polar cod is essential not only for our ability to predict ecological consequences of environmental change in the Arctic, but also for our general understanding of life history adaptations to pronounced seasonality. For polar cod, some life cycle data exist; the species reaches a maximum age of 7-8 years and becomes sexually mature between the age of 2-3 years (Hop and Gjøsæter 2013), although some specimens may reach maturity at age 1 (Nahrgang et al. 2016). Furthermore, males may reach maturity at a younger age and have a shorter life span (Nahrgang et al. 2014). Recent studies suggest that polar cod is an iteroparous species (Hop et al. 1995; Nahrgang et al. 2014) with strong indication of a group-synchronous oocyte development with determinate fecundity (Nahrgang et al. 2016). Polar cod is assumed to be a pelagic broadcast spawner, producing large floating eggs (Aronovich et al. 1975; Graham and Hop 1995), with spawning reported mainly between January and March (Andriyashev 1954; Rass 1968; Ponomarenko 2000). Polar cod eggs are buoyant and translucent with an approximate diameter of 1.6-1.9 mm (Aronovich et al. 1975; Graham and Hop 1995). Optimal conditions for embryonic development range from 0 to $3{ }^{\circ} \mathrm{C}$ and salinity 30-33 (Doroshev and Aronovich 1974; Aronovich et al. 1975; Sakurai et al. 1998). Larval development of polar cod, saffron cod and navaga has been studied experimentally (Doroshev and Aronovich 1974; Aronovich et al. 1975; Dunn and Vinter 1984; Haryu and Nishiyama 1993; Andersen et al. 1994; Sakurai et al. 1998). Bouchard and Fortier $(2008,2011)$ reviewed hatching time relative to environmental conditions and found that hatching time was extended in seas receiving large river discharges, occurring as early as January. Favorable temperature conditions in these river plumes allow more rapid egg development and help larvae achieve the motility needed for successful first feeding before the ice melts. In regions lacking a river plume, extreme temperatures (about $-1.8^{\circ} \mathrm{C}$ ) appeared to delay hatching until after ice breakup (April-July). This may also be the case in the northern Bering Sea and Chukchi Sea, where larvae are primarily associated with offshore marine waters (De Robertis et al. 2016; Kono et al. 2016).

\section{Role in food web}

Polar cod have long been recognized as a key secondary consumer and important prey for upper trophic level species in the Arctic (Bradstreet et al. 1986; Welch et al. 1992), but little was known about ontogenetic, temporal and spatial variability in their prey. Polar cod appear to be generalists feeding primarily on available zooplankton and prey composition primarily varies with size. Larger fish consume larger prey items and more benthic prey (Walkusz et al. 2013; Gray et al. 2016). The shift to benthic prey presumably reflects ontogenetic shifts in vertical distribution as larger juveniles descend in the water column toward the bottom or to join older fish in an epipelagic layer (Geoffroy et al. 2016). The vertical separation between young-of-year and older fish, and a general increase in body size with depth (Geoffroy et al. 2016), limits cannibalism, which is relatively rare in polar cod in the Pacific Arctic (Rand et al. 2013; Gray et al. 2016; Majewski et al. 2016) compared to other gadids such as walleye pollock (Gadus chalcogrammus) in the Bering Sea (Bailey 1989).

Diets of similarly sized polar cod vary among regions and by depth, reflecting regional differences in prey availability (Gray et al. 2016; Nakano et al. 2016; Majewski et al. 2016). For example, pelagic prey, in 
particular calanoid copepods, generally dominates the diet of juvenile polar cod. However, fish in the Chukchi Sea ate more benthic prey than those in the Beaufort Sea, likely reflecting higher benthic productivity in the Chukchi Sea (Grebmeier et al. 2006). Diets also changed along a depth gradient from shallow shelf stations to deep slope stations in the Beaufort Sea, although differences in this case were at least partially due to an increase in the size of polar cod with depth (Majewski et al. 2016). Polar cod in the northern Bering Sea and southern Chukchi Sea consumed a high proportion of appendicularians, which were highly abundant near the bottom during the survey period based on video transects (Nakano et al. 2016), further supporting the notion that polar cod are opportunistic feeders.

High dietary overlap has been shown between polar cod and some other forage fish such as saffron cod, juvenile walleye pollock, capelin and, to a more limited extent, Pacific sand lance (Ammodytes hexapterus), suggesting a strong potential for interspecific competition if the latter species were to expand their ranges from the subarctic into the Arctic (Hop and Gjøsæter 2013; Falardeau et al. 2014; McNicholl et al. 2015). In addition, polar cod have a coldwater stenothermic response with optimum growth near $5{ }^{\circ} \mathrm{C}$, whereas saffron cod have a much broader temperature range (Copeman et al. 2016) and the Pacific boreal gadids, walleye pollock and Pacific cod (Gadus macrocephalus), have much faster maximum growth rates at temperatures above $5{ }^{\circ} \mathrm{C}$ (Laurel et al. 2016). Similarly, Atlantic cod outgrow polar cod at $8{ }^{\circ} \mathrm{C}$ and have a competitive advantage under future warming and ocean acidification (Kunz et al. 2016). In combination, these observations suggest that polar cod are highly vulnerable to continued climate change in the Arctic marginal seas, particularly in nearshore or shelf areas that already experience considerable warming. This applies in the Chukchi Sea, where summer temperatures can reach as high as $10{ }^{\circ} \mathrm{C}$ during summer, as well as in the fjords and on the shelf of western Svalbard, where the water temperature rises above $5{ }^{\circ} \mathrm{C}$ during summer. In addition to overlapping distributions between polar cod and other gadids, polar cod and capelin co-occur in these areas, with $80 \%$ dietary overlap (Schoener's Index) in the Canadian Arctic (McNicholl et al. 2015) and $40 \%$ dietary overlap around Svalbard (Dalpadado et al. 2016).

Polar cod and other Arctic gadids also serve as key prey for a wide variety of predators including larger fish, seabirds and marine mammals (Bradstreet et al. 1986; Welch et al. 1992; Bluhm and Gradinger 2008). However, the role of predation in their population dynamics and the impacts of changes in the distribution and abundance of polar cod on predators remain poorly understood. Seasonal migrations of some of these predators may be timed to take advantage of this high-energy fish prey including piscivorous seabirds feeding on juvenile polar cod in the Chukchi Sea (Kuletz et al. 2015) and beluga whales feeding on polar cod along the Beaufort Sea shelf and slope (Loseto et al. 2009; Hauser et al. 2014). Locally, decreases in the availability of polar cod due to earlier ice retreat can have important consequences for nearshore predators with a restricted foraging range, such as Black Guillemot (Cepphus grylle mandtii) at a breeding colony (Divoky et al. 2015). In the Beaufort Sea, Black Guillemot and two other species, feeding primarily on polar cod, ringed seals (Pusa hispida) and beluga whales (Delphinapterus leucas), have shown declines in condition, growth or production during recent decades, possibly reflecting decreased availability of polar cod (Harwood et al. 2015; Moore and Stabeno 2015). Jellyfish, although an integral part of highArctic food webs (Hopcroft et al. 2005), have received less attention as potential predators on Arctic gadids, but Crawford (2016) provides evidence that the scyphomedusa Cyanea capillata has the potential to affect the small-scale distribution of polar cod in nearshore areas. Kessel et al. (2016) expand on this work to examine the roles of the environment and predator-prey dynamics on the migration of polar cod into and out of a nearshore area using acoustic telemetry.

\section{Conclusions}

Arctic gadids, in particular the polar $\operatorname{cod} B$. saida, play a pivotal role in Arctic marine ecosystems, including those of the broad Arctic shelves and the central Arctic basins. In combination, the papers assembled here suggest that the distribution, growth and abundance of these species are highly sensitive to direct temperature effects and to indirect food web effects associated with climate change. In particular, in areas with increasing summer temperatures several gadid species with a more southerly distribution, as well as capelin and other forage species, are likely to outcompete polar cod and Arctic cod in areas where they currently overlap. We hope that this special issue will contribute to a better understanding of these dynamics as climate change continues to affect marine ecosystems in a rapidly changing Arctic.

Acknowledgments We thank ESSAS (Ecosystem Studies of the Subarctic and Arctic Seas), a regional program of IMBER (International Marine Biogeochemistry and Ecosystem Research), for conceiving the workshop and for providing logistical and travel support. We thank the POLARISATION project (Research Council of Norway no. 214184/F20) and the International Arctic Science Committee (IASC) for providing generous travel support and the Natural History Museum of Denmark, University of Copenhagen, for hosting the workshop. 


\section{References}

Andersen O, Nielsen JR, Smidt E (1994) Description and comparison of eggs and yolk sac larvae of Greenland cod (Gadus ogac), Atlantic cod (Gadus morhua) and Arctic cod (Boreogadus saida) from West Greenland waters. J Northwest Atl Fish Sci 16:19-32

Andersen Ø, Frantzen M, Rosland M, Timmerhaus G, Skugor A, Krasnov A (2015) Effects of crude oil exposure and elevated temperature on the liver transcriptome of polar cod (Boreogadus saida). Aquat Toxicol 165:9-18

Andriyashev AP (1954) Fishes of the northern seas of the USSR. ANSSSR, Moscow (in Russian)

Aronovich TM, Doroshev SI, Spectorova LV, Makhotin VM (1975) Egg incubation and larval rearing of navaga (Eleginus navaga Pall.), polar cod (Boreogadus saida Lepechin) and Arctic flounder (Liopsetta glacialis Pall.) in the laboratory. Aquaculture 6:233-242

Aschan M, Karamushko OV, Byrkjedal I, Wienerroither R, Borkin IV, Christiansen JS (2009) Records of the gadoid fish Arctogadus glacialis (Peters, 1874) in the European Arctic. Polar Biol 32:963-970. doi:10.1007/s00300-009-0595-4

Astthorsson OS (2016) Distribution, abundance and biology of polar cod, Boreogadus saida, in Iceland-East Greenland waters. Polar Biol. doi:10.1007/s00300-015-1753-5

Bailey KM (1989) Interaction between the vertical distribution of juvenile walleye pollock Theragra chalcogramma in the eastern Bering Sea, and cannibalism. Mar Ecol Prog Ser 53:205-213

Bakke MJ, Nahrgang J, Ingebrigtsen K (2016) Comparative absorption and tissue distribution of ${ }^{14} \mathrm{C}$-benzo(a)pyrene and ${ }^{14} \mathrm{C}$ phenanthrene in the polar cod (Boreogadus saida) following oral administration. Polar Biol. doi:10.1007/s00300-015-1816-7

Benoit D, Simard Y, Fortier L (2008) Hydroacoustic detection of large winter aggregations of Arctic cod (Boreogadus saida) at depth in ice-covered Franklin Bay (Beaufort Sea). J Geophys Res 113:C06S90

Bluhm BA, Gradinger R (2008) Regional variability in food availability for arctic marine mammals. Ecol Appl 18:S77-S96

Boitsov VD, Dolgov AV, Krysov AI, Seliverstova EI, Shevelev MS (eds) (2013) Polar cod of the Barents Sea. PINRO Press, Murmansk (in Russian)

Bouchard C, Fortier L (2008) Effects of polynyas on the hatching season, early growth and survival of polar cod Boreogadus saida in the Laptev Sea. Mar Ecol Prog Ser 355:247-256

Bouchard C, Fortier L (2011) Circum-arctic comparison of the hatching season of polar cod Boreogadus saida: a test of the freshwater winter refuge hypothesis. Progr Oceanogr 90:105-116

Bouchard C, Mollard S, Suzuki K, Robert D, Fortier L (2016) Contrasting the early life histories of sympatric Arctic gadids Boreogadus saida and Arctogadus glacialis in the Canadian Beaufort Sea. Polar Biol. doi:10.1007/s00300-014-1617-4

Bradstreet MS, Finley KJ, Sekerak AD, Griffiths WB, Evans CR, Fabijan MF, Stallard HE (1986) Aspects of the biology of Arctic cod (Boreogadus saida) and its importance in arctic marine food chains. Can Tech Rep Fish Aquat Sci 1491:193

Christiansen JS, George SG (1995) Contamination of food by crude oil affects food selection and growth performance, but not appetite, in an Arctic fish, the polar cod (Boreogadus saida). Polar Biol 15:277-281

Christiansen JS, Hop H, Nilssen EM, Joensen J (2012) Trophic ecology of sympatric Arctic gadoids, Arctogadus glacialis (Peters, 1872) and Boreogadus saida (Lepechin, 1774), in NE Greenland. Polar Biol 35:1247-1257

Cohen DM, Inada T, Iwamoto T, Scialabba N (1990) FAO species catalogue, vol 10. Gadiform fishes of the world (Order
Gadiformes). An annotated and illustrated catalogue of cods, hakes, grenadiers and other gadiform fishes known to date. FAO, Rome

Copeman LA, Laurel BJ, Boswell KM, Sremba AL, Klinck K, Heintz RA, Vollenweider JJ (2016) Ontogenetic and spatial variability in trophic biomarkers of juvenile saffron cod (Eleginus gracilis) from the Beaufort, Chukchi and Bering Seas. Polar Biol. doi:10. 1007/s00300-015-1792-y

Crawford RE (2016) Occurrence of a gelatinous predator (Cyanea capillata) may affect the distribution of Boreogadus saida, a key Arctic prey fish species. Polar Biol. doi:10.1007/s00300-0151779-8

Dalpadado P, Hop H, Rønning J, Pavlov V, Sperfeld E, Buchholz F, Rey A, Wold A (2016) Distribution and abundance of euphausiids and pelagic amphipods in Kongsfjorden, Isfjorden and Rijpfjorden (Svalbard) and changes in their importance as key prey in a warming marine ecosystem. Polar Biol. doi:10.1007/ s00300-015-1874-X

David C, Lange B, Krumpen T, Schaafsma F, van Franeker JA, Flores H (2016) Under-ice distribution of polar cod Boreogadus saida in the central Arctic Ocean and their association with sea-ice habitat properties. Polar Biol. doi:10.1007/s00300-015-1774-0

De Robertis AD, Taylor K, Wilson CD, Farley EV (2016) Abundance and distribution of Arctic cod (Boreogadus saida) and other pelagic fishes over the US Continental Shelf of the Northern Bering and Chukchi Seas. Deep-Sea Res II. doi:10.1016/j.dsr2. 2016.03.002

Divoky GJ, Lukacs PM, Druckenmiller ML (2015) Effects of recent decreases in arctic sea ice on an ice-associated marine bird. Progr Oceanogr 136:151-161

Doroshev SI, Aronovich TM (1974) The effects of salinity on embryonic and larval development of Eleginus navaga (Pallas), Boreogadus saida (Lepechin) and Liopsetta glacialis (Pallas). Aquaculture 4:353-362

Drolet R, Fortier L, Ponton D (1991) Production of fish larvae and their prey in subarctic southeastern Hudson Bay. Mar Ecol Prog Ser 77:105-118

Dunn JR, Vinter BM (1984) Development of larvae of the saffron cod, Eleginus gracilis, with comments on the identification of gadid larvae in Pacific and Arctic waters contiguous to Canada and Alaska. Can J Fish Aquat Sci 41:304-318

Dussauze M, Camus L, Le Floch S, Pichavant-Rafini K, Geraudie P, Coquillé N, Amérand A, Lemaire P, Theron M (2014) Impact of dispersed fuel oil on cardiac mitochondrial function in polar cod Boreogadus saida. Environ Sci Pollut Res 21:13779-13788

Falardeau M, Robert D, Fortier L (2014) Could the planktonic stages of polar cod and Pacific sand lance compete for food in the warming Beaufort Sea? ICES J Mar Sci 71:1956-1965

Fortier L, Sirois P, Michaud J, Barber D (2006) Survival of Arctic cod larvae (Boreogadus saida) in relation to sea ice and temperature in the Northeast Water Polynya (Greenland Sea). Can J Fish Aquat Sci 63:1608-1616

Fossheim M, Primicerio R, Johannesen E, Ingvaldsen RB, Aschan MM, Dolgov AV (2015) Recent warming leads to a rapid borealization of fish communities in the Arctic. Nat Clim Change 5:673-677

Geoffroy M, Majewski A, LeBlanc M, Gauthier S, Walkusz W, Reist JD, Fortier L (2016) Vertical segregation of age-0 and age-1+ polar cod (Boreogadus saida) over the annual cycle in the Canadian Beaufort Sea. Polar Biol. doi:10.1007/s00300-0151811-Z

Geraudie P, Nahrgang J, Forget-Leray J, Minier C, Camus L (2014) In vivo effects of environmental concentrations of produced water on the reproductive function of polar cod (Boreogadus saida). J Toxicol Environ Health A 77:557-573 
Graham M, Hop H (1995) Aspects of reproduction and larval biology of Arctic cod (Boreogadus saida). Arctic 48:130-135

Gray BP, Norcross BL, Blanchard AL, Beaudreau AH, Seitz AC (2016) Variability in the summer diets of juvenile polar cod (Boreogadus saida) in the northeastern Chukchi and western Beaufort Seas. Polar Biol. doi:10.1007/s00300-015-1796-7

Grebmeier JM, Cooper LW, Feder HM, Sirenko BI (2006) Ecosystem dynamics of the Pacific-influenced Northern Bering and Chukchi Seas in the Amerasian Arctic. Progr Oceanogr 71:331-361

Harwood LA, Smith TG, George JC, Sandstrom SJ, Walkusz W, Divoky GJ (2015) Change in the Beaufort Sea ecosystem: diverging trends in body condition and/or production in five marine vertebrate species. Progr Oceanogr 136:263-273

Haryu T, Nishiyama T (1993) Postlarval morphology of walleye pollock, Theragra chalcogramma (Pallas) and Arctic cod, Boreogadus saida (Lepechin). Sci Rep Hokkaido Fish Exp Stn 42:121-133

Hauser DDW, Laidre KL, Suydam RS, Richard PR (2014) Population-specific home ranges and migration timing of Pacific Arctic beluga whales (Delphinapterus leucas). Polar Biol 37:1171-1183

Havforskningsrapporten (2015) Fisken og havet, Special Isse 1-2015. ISSN 08020620 (in Norwegian)

Hop H, Gjøsæter H (2013) Polar cod (Boreogadus saida) and capelin (Mallotus villosus) as key species in marine food webs of the Arctic and the Barents Sea. Mar Biol Res 9:878-894

Hop H, Trudeau VL, Graham M (1995) Spawning energetics of Arctic cod (Boreogadus saida) in relation to seasonal development of the ovary and plasma sex steroid levels. Can J Fish Aquat Sci 52:541-550

Hop H, Welch HE, Crawford RE (1997) Population structure and feeding ecology of Arctic cod schools in the Canadian High Arctic. In: Reynolds J (ed) Fish ecology in Arctic North America. American Fisheries Society Symposium 19, Bethesda, Maryland, pp 68-80

Hopcroft RR, Clarke C, Nelson RJ, Raskoff KA (2005) Zooplankton communities of the Arctic's Canada Basin: the contribution by smaller taxa. Polar Biol 28:197-206

Jordan AD, Møller PR, Nielsen JG (2003) Revision of the Arctic cod genus Arctogadus. J Fish Biol 62:1339-1352

Kessel ST, Hussey NE, Crawford RE, Yurkowski DJ, O'Neill CV, Fisk AT (2016) Distinct patterns of Arctic cod (Boreogadus saida) presence and absence in a shallow high Arctic embayment, revealed across open-water and ice-covered periods through acoustic telemetry. Polar Biol. doi:10.1007/s00300015-1723-y

Kono Y, Sasaki H, Kurihara Y, Fujiwara A, Yamamoto J, Sakurai Y (2016) Distribution pattern of polar cod (Boreogadus saida) larvae and larval fish assemblages in relation to oceanographic parameters in the northern Bering Sea and Chukchi Sea. Polar Biol. doi:10.1007/s00300-016-1961-7

Kuletz KJ, Ferguson MC, Hurley B, Gall AE, Labunski EA, Morgan TC (2015) Seasonal spatial patterns in seabird and marine mammal distribution in the eastern Chukchi and western Beaufort seas: identifying biologically important pelagic areas. Progr Oceanogr 136:175-200

Kunz KL, Frickenhaus S, Hardenberg S, Johansen T, Leo E, Pörtner H-O, Schmidt M, Windisch HS, Knust R, Mark FC (2016) New encounters in Arctic waters: a comparison of metabolism and performance of polar cod (Boreogadus saida) and Atlantic cod (Gadus morhua) under ocean acidification and warming. Polar Biol. doi:10.1007/s00300-016-1932-z

Laurel BJ, Spencer M, Iseri P, Copeman LA (2016) Temperaturedependent growth and behavior of juvenile Arctic cod (Boreogadus saida) and co-occurring North Pacific gadids. Polar Biol. doi:10.1007/s00300-015-1761-5
Logerwell E, Busby M, Carothers C, Cotton S, Duffy-Anderson J, Farley E, Goddard P, Heintz R, Holladay B, Horne J, Johnson S, Lauth B, Mouton L, Neff D, Norcross B, Paker-Stetter S, Seigle J, Sformo T (2015) Fish communities across a spectrum of habitats in the western Beaufort Sea and Chukchi Sea. Progr Oceanogr 136:115-132

Loseto LL, Stern GA, Connelly TL, Deibel D, Gemmill B, Prokopowicz A, Fortier L, Ferguson SH (2009) Summer diet of beluga whales inferred by fatty acid analysis of the eastern Beaufort Sea food web. J Exp Mar Biol Ecol 374:12-18

Madsen ML, Nelson RJ, Fevolden S-E, Christiansen JS, Præbel K (2016) Population genetic analysis of Euro-Arctic polar cod Boreogadus saida suggests fjord and oceanic structuring. Polar Biol. doi:10.1007/s00300-015-1812-y

Majewski AR, Walkusz W, Lynn BR, Atchison S, Eert J, Reist JD (2016) Distribution and diet of demersal Arctic cod, Boreogadus saida, in relation to habitat characteristics in the Canadian Beaufort Sea. Polar Biol. doi:10.1007/s00300-015-1857-y

McBride MM, Filin A, Titov O, Stiansen JE (eds) (2014) IMR/ PINRO update of the "Joint Norwegian-Russian environmental status report on the Barents Sea Ecosystem" giving the current situation for climate, phytoplankton, zooplankton, fish, and fisheries during 2012-2013. IMR/PINRO Joint Report Series 2014(1)

McNicholl DG, Walkusz W, Davoren GK, Majewski AR, Reist JD (2015) Dietary characteristics of co-occurring polar cod (Boreogadus saida) and capelin (Mallotus villosus) in the Canadian Arctic, Darnley Bay. Polar Biol. doi:10.1007/s00300-015-1834-5

Mecklenburg C, Steinke D (2015) Ichthyofaunal Baselines in the Pacific Arctic Region and RUSALCA Study Area. Oceanography 28:158-189

Mecklenburg CW, Mecklenburg TA, Thorsteinson LK (2002) Fishes of Alaska. American Fisheries Society, Bethesda

Mecklenburg CW, Byrkjedal I, Karamushko OV, Møller PR (2014) Atlantic fishes in the Chukchi Borderland. Mar Biodiv 44:127-150

Melnikov IA, Chernova NV (2013) Characteristics of under-ice swarming of polar cod Boreogadus saida (Gadidae) in the Central Arctic Ocean. J Ichthyol 53:7-15

Michaud J, Fortier L, Rowe P, Ramseier R (1996) Feeding success and survivorship of Arctic cod larvae, Boreogadus saida, in the Northeast Water polynya (Greenland Sea). Fish Oceanogr 5:120-135

Moore SE, Stabeno PJ (2015) Synthesis of Arctic Research (SOAR) in marine ecosystems of the Pacific Arctic. Progr Oceanogr 136:1-11

Mueter FJ, Litzow MA (2008) Sea ice retreat alters the biogeography of the Bering Sea continental shelf. Ecol Appl 18:309-320

Nahrgang J, Camus L, Carls MG, Gonzalez P, Jonsson M, Taban IC, Bechmann RK, Christiansen JS, Hop H (2010) Biomarker responses in polar cod (Boreogadus saida) exposed to the water soluble fraction of crude oil. Aquat Toxicol 97:234-242

Nahrgang J, Varpe $\varnothing$, Korshunova E, Murzina S, Hallanger IG, Vieweg I, Berge J (2014) Gender specific reproductive strategies of an Arctic key species (Boreogadus saida) and implications of climate change. PLoS One 9:e98452

Nahrgang J, Storhaug E, Murzina SA, Delmas O, Nemova NN, Berge J (2016) Aspects of reproductive biology of wild-caught polar cod (Boreogadus saida) from Svalbard waters. Polar Biol. doi:10.1007/s00300-015-1837-2

Nakano T, Matsuno K, Nishizawa B, Iwahara Y, Mitani Y, Yamamoto J, Sakurai Y, Watanuki Y (2016) Diets and body condition of polar cod (Boreogadus saida) in the northern Bering Sea and Chukchi Sea. Polar Biol. doi:10.1007/s00300-015-1769-x

Nelson RJ, Bouchard C (2013) Final report: arctic cod (Boreogadus saida) population structure and connectivity as examined with 
molecular genetics. NPRB Project 1125. Québec-Océan, Dèpartement de Biologie, Université Laval, Québec, QC, Canada

Norcross BL, Holladay BA, Busby MS, Mier KL (2010) Demersal and larval fish assemblages in the Chukchi Sea. Deep-Sea Res II 57:57-70

Ponomarenko VP (2000) Eggs, larvae, and juveniles of polar cod Boreogadus saida in the Barents, Kara, and White Seas. J Ichthyol 40:165-173

Pörtner HO, Playle RC (eds) (1998) Cold ocean physiology. Society for Experimental Biology Seminar Series 66. Cambridge University Press, Cambridge

Rand KM, Whitehouse A, Logerwell EA, Ahgeak E, Hibpshman R, Parker-Stetter S (2013) The diets of polar cod (Boreogadus saida) from August 2008 in the US Beaufort Sea. Polar Biol 36:907-912

Rass TS (1968) Spawning and development of polar cod. Rapp P-V Réun Cons Perm Int Explor Mer 158:135-137

Renaud PE, Berge J, Varpe Ø, Lønne OJ, Nahrgang J, Ottesen C, Hallanger I (2012) Is the poleward expansion by Atlantic cod and haddock threatening native polar cod, Boreogadus saida? Polar Biol 35:401-412

Sakurai Y, Ishii K, Nakatani T, Yamaguchi H, Anma G, Jin M (1998) Reproductive characteristics and effects of temperature and salinity on the developmenht and survival of eggs and larvae of Arctic cod (Boreogadus saida). In: Ohtani et al (eds) Oyashio region and Bering Sea ecosystems, vol 45. Mem Fac Fish Hokkaido Univ, pp 77-89

Süfke L, Piepenburg D, von Dorrien CF (1998) Body size, sex ratio and diet composition of Arctogadus glacialis (Peters, 1874) (Pisces: Gadidae) in the Northeast Water Polynya (Greenland). Polar Biol 20:357-363

von Dorrien CF, Piepenburg D, Schmid MK (1991) On the abundance of Arctic cod Arctogadus glacialis in Northeast Water. Polar Rec 27:362-364

Walkusz W, Majewski A, Reist JD (2013) Distribution and diet of the bottom dwelling Arctic cod in the Canadian Beaufort Sea. J Mar Syst 127:65-75

Wang M, Overland JE (2009) A sea ice free summer Arctic within 30 years? Geophys Res Lett 36:L07502. doi:10.1029/ 2009GL037820

Welch HE, Bergmann MA, Siferd TD, Martin KA, Curtis MF, Crawford RE, Conover RJ, Hop H (1992) Energy flow through the marine ecosystem of the Lancaster Sound region, Arctic Canada. Arctic 45:343-357

Wolotira RJ Jr(1985) Saffron cod, Eleginus gracilis, in western Alaska, the resource and its potential US Department of Commerce, NOAA Technical Memorandum NFMS-F/NWC-79 